\title{
Terras, ouro e cativeiro: a ocupação do aldeamento dos Guarulhos nos séculos XVI e XVII ${ }^{1}$
}

\author{
José Carlos Vilardaga*
}

\author{
VILARDAGA, J. Terras, ouro e cativeiro: a ocupação do aldeamento dos Guarulhos nos \\ séculos XVI e XVII. R. Museu Arq. Etn., 26: 42-61, 2016
}

Resumo: Neste texto - apoio documental e do campo da história social ao trabalho de investigação arqueológica da região de Guarulhos (PIPAG) -, analisa-se a expansão e ocupação colonial no território que configuraria mais tarde o município guarulhense. Centrada nos séculos XVI e XVII, a pesquisa busca acompanhar o assentamento de colonos em datas e sesmarias, e as formas de transmissão dessas propriedades entre algumas poucas famílias. Investiga as formas de beneficiamento dessas terras, dentre elas a produção agrícola, criação pastoril e principalmente a mineração de ouro, essa última, atividade fundamental na exploração do território e pouco analisada na historiografia. Por fim, o texto discute as interações estabelecidas entre os colonos e os índios, assentados no aldeamento de Nossa Senhora da Conceição dos Guarulhos e imediações, problematizando as formas de agência indígena.

Palavras-chave: Expansão colonial; Agência indígena; Mineração de ouro; Nossa Senhora da Conceição dos Guarulhos.

\section{Introdução}

E m abril de 1652, o casal João Sutil de Oliveira e Maria Ribeira foram mortos por índios Guarulhos no sítio que possuíam na região que hoje tem o nome dos índios, seus algozes. Deixaram dois filhos pequenos, Bastião, de 4 anos, e Izabel, de 6, que não foram atingidos pela fúria dos "gentios". Isso ou porque os índios os pouparam ou porque estavam em outro lugar, como a casa de taipa de pilão e telha de barro que seus pais tinham na vila de São Paulo de Piratininga. Pelos bens inventaria-

1 Parte da pesquisa para a elaboração deste texto foi feita pela bolsista PIBIC-UNIFESP, Juliana Marques do Nascimento.

(*) Historiador, Professor do Departamento de História da UNIFESP. dos do casal, percebe-se que não se tratava de uma família de muitas posses. Alguns tecidos básicos, como cobertores, fronhas e anáguas, um colchão usado de lã e outros poucos objetos constituíam o grosso dos bens do casal. A atividade agrícola também é insondável, já que sabemos que apenas existiam alguns cavalos, "sal de angola" e um tear, esse na casa da vila. A presença desse objeto era muito comum nas casas dos moradores de São Paulo, pois o cultivo do algodão era muitíssimo praticado nas terras do planalto. Apesar do uso de técnicas europeias, grande parte dos tecelões era indígena. Quando, anos depois, em 1661, o genro do defunto João Sutil, Sebastião das Pontes, reivindicou sua parte no inventário, fez referência a um índio chamado Lucas Tecelam.

Contudo, a presença de um gibão de armas, além de quatro escopetas, uma velha espada de "uso antigo" e três correntes de três 
braças $(6,60 \mathrm{~m})$, com seus colares, revela um "caçador" de índios, típico personagem que ajudaria a configurar o mal-afamado "bandeirante". A atividade de apresamento indígena da qual participava João envolvera também seu irmão, Simão Sutil, que falecera no sertão em 1650, deixando dois filhos pequenos. João teria tomado parte da companhia de homens em armas que Salvador Correia de Sá e Benevides organizou para enfrentar os holandeses em Pernambuco no ano de 1639. Os registros da Câmara de São Paulo mostram como muitos homiziados por crimes de entrada no sertão e apresamento indígena barganharam perdão enviando filhos ou parentes para lutarem nesse conflito. Talvez tenha sido este o caso de João, filho que era de um notório sertanista, Francisco Sutil de Oliveira.

Seja como for, o plantel de escravos de João, apresentados eufemisticamente como "gente forra", era composto de 12 casais e quase duas dezenas de solteiros, entre homens e mulheres. John Monteiro (1998), que analisou brevemente esse caso, entende que era um plantel de índios recém-descidos do sertão, já que grande parte dos casais apresentavam nomes duplos, como Simão e Simoa, Luis e Luisa, Ambrósio e Ambrósia, o que denotaria uma sucessão de batismos e casamentos rápidos e apressados. Além desses, 11 estavam fugidos, provavelmente aproveitando o incidente, ou dele participando ativamente. Anos depois, quando o pai de João prestou contas do inventário do filho, ele afirmou que somente quatro dos casais ainda eram vivos, e que "ao tempo que mataram a seu filho e nora os Guarulhos matadores levaram alguns moços os quais até agora se não sabia delas e os mais eram mortos”. Pela declaração, pode-se deduzir que índios Guarulhos de fora da propriedade atacaram e resgataram eventuais parentes cativos. De qualquer forma, a violência do evento deve ter sido grande, já que somente em agosto conseguiu-se entrar na propriedade para lançar os bens do sítio onde o casal foi morto. Ali viu-se uma casa bem simples, de taipa de mão, coberta com palha e com apenas uma porta, e constatou-se a presença de um cavalo moribundo, em função de uma flechada (I\&T, v. 42: 127-171).
A morte do casal nessa década de 1650 não pode ser considerada como um fato isolado nem fortuito. Nesse mesmo ano, na propriedade de Antônio Pedroso de Barros, uma revolta levou à morte esse rico proprietário e sertanista. Suas terras, para as bandas de Juqueri, nas proximidades do atual município de Mairiporã, produzia trigo em abundância e tinha cerca de 500 índios em seu plantel. Pedroso de Barros ainda teve tempo de fazer seu testamento, mas já "no artigo da morte". Entre seus índios, existiam muitos "sem nome" e que não sabiam falar o português ou a língua geral de origem tupi. Eram, também, índios recém-descidos de alguma expedição ao sertão. (Inventários e Testamentos, v. 20) $\mathrm{O}$ evento parece ter sido tão traumático que, em 1662, Leonor Siqueira, viúva do irmão de Antonio, chegou a vender 60 de seus índios das suas terras em Juqueri para o outro cunhado, Fernão Pedroso de Barros, temerosa de um levante, já que Fernão sugeriu que os índios andavam amotinados.

Ainda na década de 1660, as revoltas nas terras de Manuel de Morais, Ascenso Morais Dantas, Fernão Bicudo Tavares e Francisco Coelho da Cruz revelam um clima de conflito duradouro. Nesses casos, conforme uma Ata da Câmara relata, os índios andavam alvoroçados por causa de algumas notícias de que o governador Salvador Correa de Sá e Benevides estava apregoando a liberdade de todos os gentios. (Atas da Câmara da Vila de São Paulo, v. VI, 02/11/1660)

As terras ao longo dos rios Juqueri e Jaguari, bem como as que iam na direção de Mogi, margeando o Tietê, eram todas de ocupação colonial relativamente tardia em relação ao núcleo planaltino. Elas tornaram-se gradativamente permeadas de plantações de trigo, milho e algodão, e tinham na mão de obra indígena, apresada continuamente nos sertões, a fonte principal de trabalhadores. Não à toa, portanto, ali foi um dos principais focos de revolta, e local de tensões permanentes entre indígenas e colonos. Nas proximidades de Mogi, por exemplo, em 1660, os índios de Bartolomeu Nunes do Passo mataram-no e destruíram todos os seus bens, ao ponto de a viúva não ter o que declarar por ocasião do inventário. 
Ainda para John Monteiro (1998), a série de revoltas desses anos encontra alguma explicação numa determinada conjuntura, pensada por esse autor como uma espécie de crise geral. A sucessão de expedições de apresamento indígena teria provocado uma elevação alarmante dos níveis populacionais. Ele indica a média de oito índios para cada branco nas zonas rurais. Tal densidade pressupunha uma mistura étnica de grupos muito variados e uma dificuldade sistêmica de abastecimento. Tal crise alimentar seria evidenciada pelos preços das plantações de milhos nesses anos, que subiram muitíssimo (Monteiro, 1998). Além disso, havia um clima de revolta em toda a região, já que duas grandes famílias haviam retomado uma guerra aberta. Os Pires e os Camargo deram início, em 1641, a uma luta de famílias depois que Fernando de Camargo matou Pedro Taques com uma facada na porta da igreja matriz da vila de São Paulo. A rinha duraria muitos anos, com momentos de trégua, mas só se encerraria depois de um acordo em torno dos cargos da Câmara na década de 1670 (Pinto, 1980).

A maioria das revoltas de cunho indígena desses anos teve como protagonistas ou os índios Guarulhos ou os chamados Guaianases. Ambos eram bem conhecidos e historicamente presentes nos inventários desde o final do século XVI. Contudo, nas primeiras décadas do século XVII, os Carijós (Guaranis) passaram a ser hegemônicos entre os donos de escravos indígenas de São Paulo. Até a grande derrota dos bandeirantes de São Paulo em M'Bororé, em 1641, o Guairá paraguaio foi livre palco da ação bandeirante que, de lá, desceu milhares de Guaranis e Temiminós (esses Tupis). Depois da década de 1640, com o acesso aos Guaranis cada vez mais dificultado, os bandeirantes de São Paulo teriam se voltado novamente aos tradicionais grupos que viviam nas proximidades da vila, a esmagadora maiores deles de grupos Jê, caçadores e coletores. É assim, portanto, que novas levas de Guaianases e Guarulhos, refugiados desde a década de 1590 na Serra da Mantiqueira ou para além da Cantareira, voltaram a ser capturados em grandes quantidades. Esses índios recém-descidos nas décadas de 1640 e 1650 protagonizarão os maiores conflitos e revoltas. A maioria desses indígenas era automaticamente distribuída entre os colonos que armavam as expedições - como o caso dos Sutil de Oliveira -, mas alguns eram direcionados para os aldeamentos que cercavam São Paulo (Monteiro, 1998).

Dentre esses, destacavam-se os pioneiros jesuíticos de São Miguel e Pinheiros, o ainda quinhentista Nossa Senhora da Conceição dos Guarulhos, e os seiscentistas de Barueri, Itaquaquecetuba, Cotia, Embu e Carapicuíba. Eles foram, desde os finais do século XVI, pontos de discórdia e conflito entre jesuítas e colonos. Os três primeiros, em especial, eram vistos como de ação exclusiva dos padres jesuítas, sobre as quais os colonos guardaram ainda um pudor inicial, o que não necessariamente acontecia com as outras, como revela o caso da invasão armada da aldeia de Barueri pelos colonos em 1633, e as queixas contra a presença dos padres em Cotia e Carapicuíba na década de 1620 (Vilardaga, 2014). De todo modo, depois da expulsão dos jesuítas da vila de São Paulo em 1640, no episódio conhecido como "botada para fora dos padres", as antigas aldeias da Companhia de Jesus passaram a ser totalmente administradas pelas autoridades coloniais da vila e suas terras - algumas, como São Miguel, grandes sesmarias doadas na década de 1580 -, passaram a ser "aforadas" e ocupadas pelos colonos (Petrone, 1995). A linha que seguia das terras de São Miguel, na margem sul - e provavelmente também a norte - do Anhembi (Tietê), passando pelas terras de Nossa Senhora da Conceição, mais ao norte, foram gradativamente distribuídas a partir da década de 1610, com doações de sesmarias nas franjas das terras das aldeias. Mas foi na década de 1640 que as áreas propriamente indígenas passaram a ser efetivamente - e continuamente - ocupadas e beneficiadas. Os índios acabaram expulsos ou incorporados aos plantéis escravistas dos proprietários locais. Como exemplo, citemos um relatório de 1679 que denunciava que a aldeia de Nossa Senhora da Conceição havia passado de 800 índios, na década de 1640, para $70 \mathrm{em} 1679$ (Petrone, 1995). 


\section{Expansão agrícola e terras do aldeamento}

A região ocupada pelo antigo aldeamento de Nossa Senhora da Conceição de Guarulhos deveria compreender as terras conhecidas como Caucaia (que mais tarde darão a base da freguesia de Guarulhos) e a área ao longo do rio Jaguari. Os primeiros ocupantes desses territórios foram Miguel de Almeida Miranda e seu sobrinho Jerônimo da Veiga (Monteiro, 1998). Nos anos 1650, a área será importante ponto de produção de trigo, e três genros de Miguel serão proprietários ali, em especial Henrique da Cunha Gago (I\&T, v. 1, 207-280). Miguel, já proprietário de sesmaria nas terras da aldeia desde 1625 , oficializou a posse de um outro pedaço de terra em 1639, "aonde um índio marumumin por nome Pedro com outros parentes seus tiveram suas roças", subindo rumo ao rio Atibaia e fazendo fronteira a leste com o rio Jaguari (Sesmarias, v. 1: 318-322). Essa informação parece já denotar uma expropriação direta de terras indígenas.

Mais ao sul, a ocupação foi desencadeada sob o pretexto da exploração mineral. Geraldo Correa exploraria o ouro ao longo do rio Baquiruvu em região que, até hoje, guarda a toponímia das Lavras Velhas do Geraldo. Geraldo foi nomeado capitão branco da aldeia, o que sacramentaria o processo de ocupação dos colonos das terras de Nossa Senhora da Conceição de Guarulhos. Na outra margem do rio Tietê, nas terras pertencentes à sesmaria da aldeia de São Miguel, o processo será bastante semelhante. Os colonos brancos começaram a ocupar a outra margem do rio, teoricamente fora dos limites da sesmaria, ainda na década de 1620 , no entorno da Capela do Bonsucesso, em terras de Francisco Cubas, sertanista e plantador. ${ }^{2}$

A região hoje pertence ao município de Guarulhos, mas sua história é efetivamente muito mais vinculada a São Miguel que a Nossa Senhora da Conceição. Para John Monteiro (1998), o exemplo da Capela de Bonsucesso só

2 Os limites da sesmaria de São Miguel são controversos. Para alguns estudiosos, como John Monteiro, ela deveria cobrir áreas nas duas margens do Anhembi, em território que hoje configura os bairros dos Pimentas e Bonsucesso, em Guarulhos. reforçaria os evidentes vínculos que existiriam entre a fundação de capelas rurais - feita por grandes proprietários-sertanistas - e a chegada de grandes levas de indigenas descidos do sertão. É o caso de Afonso Sardinha e a capela de Carapicuíba, de Fernão Pais de Barros e a Capela de Santo Antônio, em São Roque; e a capela de Nossa Senhora da Expectação do Ó, vinculada a Manoel Preto.

Dentre os personagens que ocuparam gradativamente as terras onde estavam alocados os índios chamados de Maromomis ou Guarulhos, mais tarde aldeamento de Nossa Senhora da Conceição, estava João Sutil de Oliveira, nosso bandeirante assassinado. Em verdade, grande parte da ascendência de João já havia participado da ocupação das terras da região. Seu pai, Francisco Sutil de Oliveira, foi um dos primeiros donos de sesmarias nas "bandas do além" Anhembi, que configuram áreas hoje pertencentes ao município de Guarulhos. A mãe, Izabel da Costa, era filha de João da Costa e Inês Camacho. Izabel, quando faleceu, em 1623, encomendou duas missas a Nossa Senhora da Conceição na aldeia de Guarulhos e apresentou uma carta de terras de meia légua "onde estavam os guarumemins" e outras terras herdadas de seu pai (I\&T, v. 12: 331-347). O avô materno de João Sutil, João da Costa, casado com Inês Camacho, foi homem de confiança do governador geral do Brasil, D. Francisco de Souza, que se estabeleceu em São Paulo entre 1599 e 1603, num primeiro momento, e entre 1609 e 1611, numa segunda oportunidade. O governador, movido pela missão de encontrar ouro e prata nas terras da colônia, mudara-se pra São Paulo atrás das notícias de descobertas minerais feitas pelos Sardinhas. Na vila do planalto, D. Francisco organizou uma estrutura administrativa e econômica para beneficiar as supostas minas e dinamizar sua exploração, o que incluía o fomento de uma economia agrícola complementar ancorada na produção de trigo, milho e algodão (Vilardaga, 2014). O território hoje ocupado pelo município de Guarulhos foi, juntamente com São Miguel, uma das fronteiras fundamentais dessa expansão.

João da Costa foi parte desse esforço na montagem de uma "jurisdição das minas" em 
São Paulo, na qual foi inicialmente mamposteiro dos cativos, função criada em Portugal no século XIV e que tinha o objetivo de arrecadar recursos para "libertar" cativos. Nascido para atender, especialmente, aos prisioneiros feitos pelos árabes na Península Ibérica e no norte da África, nas Américas ele se adaptou ao cativeiro indígena. Formalmente, cumpria a função de salvaguardar os índios capturados em guerra justa e promover sua alforria. Por isso mesmo, Costa era o possuidor de um exemplar das Ordenações do Reino, como consta do inventário de sua mulher. Foi também repartidor de terras e avaliador dos órfãos, mas depois da morte da esposa, foi se desfazendo de seus bens e acabou se recolhendo à ermida de Santo Antônio, na vila de São Paulo, onde se tornou ermitão. Tinha conhecimentos de física e atuava como "barbeiro", legando em seu inventário de 1639 vários objetos relacionados a essa atividade (I\&T, v. 12: 348-370) Suas terras em Guarulhos eram muito provavelmente herança e/ou dote de seu sogro, Domingos Luiz, conhecido como o Carvoeiro, um dos pioneiros da "colonização" do Planalto de Piratininga. O apelido era uma referência à Santa Maria de Carvoeira, freguesia onde ficava Marinhota, terra natal de Domingos. Ele fora eleito "capitão do gentio" em 1563, quando a vila vinha de um período de grave conflito indígena que quase resultou em sua destruição, e casou-se com uma das filhas de João Ramalho, Ana Camacho, defensor da vila ao lado do chefe Tibiriçá nos conflitos de 1562 (Monteiro, 2004).

O Carvoeiro era carpinteiro e participou da construção da igreja dos jesuítas e da igreja do Guaré, mais tarde Nossa Senhora da Luz (Franco, 1954). Podemos vislumbrar algo de sua personalidade pelo depoimento do Padre José de Anchieta que comenta, em carta de 1579, ao capitão-mor Jerônimo Leitão, que a obra da igreja estava atrasada pois os índios andavam amotinados por "medo do carvoeiro" (Cartas, 1933). Sujeito aparentemente irascível, em 1593 entrou em conflito com o capitão-mor da Capitania de São Vicente, Jorge Correa. Domingos acusou-o de roubar uma índia e levá-la para a vila litorânea (Ferreira, 1971). Diante das acusações, o capitão-mor autorizou o querelante a pegar arbitrariamente qualquer índia das aldeias do planalto, o que incomodou os oficiais da Câmara de São Paulo, que imediatamente notificaram que ninguém deveria "bulir com os índios forros", pois eles já estavam "muito escandalizados e se poderão agravar mais". $\mathrm{O}$ aviso tinha um destino certo: os índios "guaramemis", de onde o Carvoeiro prometera sacar sua "dívida" (ACVSP, 1967, v. 1, 31/07/1593).

De fato, os anos de 1590 até 1595 foram anos bastante tumultuados na vila de São Paulo e seus arredores. Um levante indígena na aldeia de Pinheiros resultou, para horror dos padres, na destruição da imagem de Nossa Senhora do Rosário. Além disso, os índios de "Mogi" haviam trucidado uma expedição de colonos brancos e índios Tupis na região e o clima de pânico espalhara-se pela vila (Monteiro, 2004). Assim, com os ânimos todos sobressaltados, não convinha permitir que algum colono fosse se apropriar de uma indígena das aldeias. Em agosto do mesmo ano, em nova sessão, os oficiais reforçaram a proibição de não se ir à terra dos Guaramimis e Goianazes, "por haver para isso muitas razões, e por se não alevantarem com os do sertão que estavam alevantados". O clima turbulento fora atestado por Afonso Sardinha, que enviara um de seus índios, um "guaramimi cristão", para averiguar o nível da revolta. A sessão ainda recomendou que não se fizessem entradas nas terras dos Guaramimis (ACVSP, v. 1, 15/08/1593).

Além do Carvoeiro, outra das primeiras famílias a possuir terras na região que hoje corresponde ao território de Guarulhos foi a Pires. João Pires era filho de Salvador Pires e Mécia Fernandes, esta neta de Piquerobi, antigo cacique de Ururaí, origem do que viria a ser o aldeamento de São Miguel. Não à toa, um dos genros de Salvador, Bartolomeu Bueno, foi um dos pioneiros na apropriação das terras do aldeamento da margem sul do rio Tietê (Bontempi, 1970).

A viúva de João Pires, Méssia Rodrigues, legou em testamento uma légua de terras na "paragem serro das minas de Geraldo Correa até Juquery-mirim" e mais três datas anexas, além de outra terra em Urubuapira, que corria pelo "serro arriba para o sertão". Sua fazenda se 
estendia até o rio Baquiruvu e foi concedida em sesmaria no ano de 1619. Ali, os Pires criavam gado e plantavam trigo e cereais, avançando claramente sobre as terras que deveriam pertencer à aldeia de Nossa Senhora da Conceição (I\&T, v. 17: 113-158). O fenômeno de dilapidação das terras indígenas, concedidas em sesmarias no começo do século XVII, atingiu primeiro as terras de São Miguel, no qual os Bueno cumpriram um papel decisivo, e depois as de Conceição dos Guarulhos, já na segunda década do mesmo século, na qual os Pires, ligados fortemente aos Bueno, seriam um dos protagonistas essenciais.

O irmão de João, Salvador Pires de Medeiros, tinha terras um pouco mais além, para as bandas de Juqueri. Ali ele foi um dos pioneiros de ocupação ao lado de sua mulher, Inês Monteiro de Alvarenga, figura em torno da qual teria se desenrolado alguns dos episódios mais dramáticos da chamada luta entre Pires e Camargo, conforme as narrativas dos cronistas setecentistas de São Paulo. Depois do assassinato de Fernão Taques ainda em 1641, um novo episódio da contenda seria a morte de Alberto Pires, filho de Salvador e Inês. Alberto, casado com uma Camargo, teria assassinado a esposa num arroubo de ciúmes. Preso e arrastado para a Bahia, as crônicas contam que ele foi jogado no mar pelos seus vigilantes, alguns deles aliados dos Camargo. A mãe, Inês, movida pelo espírito de vingança, teria mantido a luta contra os desafetos Camargo por muitos anos ainda (Pinto, 1980). Seja como for, a documentação mostra como João Pires, cunhado de Inês e um dos principais líderes dos Pires, foi um dos grandes articuladores da paz entre as famílias, estabelecida uma primeira vez em 1655. Ao lado de Francisco Nunes Siqueira, seu genro e lembrado pelas crônicas como "redentor da pátria", costuraram o acordo que estabeleceu a paridade entre Camargos e Pires na Câmara de São Paulo. Pires teria sido ainda um dos responsáveis pelo acordo que permitiu o retorno dos jesuítas a São Paulo em 1653. Dessa forma, importantes eventos relacionados a esse conflito familiar em São Paulo ocorreram em torno das terras e propriedades que os Pires possuíam para as bandas do Baquirivu e Juqueri.
Francisco Nunes da Siqueira, como genro de João Pires, também se estabeleceu ao longo do rio Baquirivu, e possuía terras por um "caminho que vai dar na aldeia de Nossa Senhora da Conceição", em direção ao Juqueri. Seu vizinho era Francisco Rodrigues Sapateiro, que ganhou terras ali juntamente com seu sogro, Luis Furtado (Sesmarias, v. 1: 301-304). Sapateiro faleceu em 1652, mesmo ano de João Sutil, e tinha muitas ferramentas e instrumentos para o plantio e beneficiamento de trigo, algodão e mandioca. Possuía três teares e alguns fardos de algodão em seu inventário (I\&T, 42: 37-54). Um de seus genros, Domingos Fernandes, que era dono de 3.000 braças de terra na própria "tapera dos guarumumis", ajudava a configurar ainda mais a explícita invasão do núcleo de terras indígenas (Sesmarias, v. 1: 356-359).

$\mathrm{O}$ algodão foi provavelmente uma das principais bases produtivas da região, ao lado do gado e do trigo. Um dos grandes produtores e comerciantes de algodão em São Paulo, inclusive com mercadoria posta no porto de Buenos Aires, foi Antonio Pedroso de Alvarenga, cunhado de Salvador Pires. Pedroso possuía terras no Cabuçu (I\&T, 4: 49-75), e foi também sertanista e capitão de uma grande bandeira que percorreu o Guairá entre 1615 e 1618, de onde trouxe muitos Carijós.

Por fim, outro personagem significativo na ocupação colonial do território foi Henrique da Cunha, alcunhado o Velho, falecido em pleno sertão em 1623. Para Afonso Taunay, era um homem "opulento" e grande apresador de índios (Taunay, 1975). Quando de seu inventário, em 1624, possuía 150 braças de terras no Urubuapira, mesma região dos Pires. Em seu sítio, deixou sua casa e uma "casa de negros". Legou muitas roupas, ferramentas, arreteis de fio de algodão, gado, e lavouras de feijão e mandioca, além de um roçado de milho no Baquirivu. Tinha vários índios "forros", inclusive um "guatumimim" que legou ao genro, e Tememinós, Carijós, Pés-largos e diversos sem nome, o que também pode indicar índios recém-chegados do sertão. Henrique ainda possuía uma negra da Guiné com um filho de peito, casada com um índio, e mãe de dois "mulatos". Henrique da Cunha deixou em testamento duas varas de al- 
godão à igreja de Nossa Senhora da Conceição, entregues para Francisco Borges, que deveria gerir os bens da casa de Conceição, pois ele mesmo devia uma sela "da casa do padre João Alves" a um dos filhos de Henrique. Esse padre é o provável construtor da Igreja de Conceição (I\&T, v. 1: 207-280). Borges era casado com uma das filhas de Sebastião Gil, dono de sesmaria na região, com sítio em ibutiratim, e dono de diversos Carijós e Guaianases, alguns deles fugidos (I\&T, 39: 87-122).

É possivel acompanhar o desenvolvimento patrimonial de Henrique da Cunha através dos inventários de suas duas primeiras esposas. A primeira mulher, Izabel Fernandes, falecida em 1599, era filha de Salvador Pires e irmã de João Pires, o Velho. Através do dote da esposa, Henrique ficou com terras na "banda de além", em Urubuapira, e já tinha nessa ocasião algum gado, algumas poucas roupas e uma "canoa de casca”. Os vínculos entre os Bueno e os Pires, controlando as duas bandas do rio, fica já evidente na dívida do carpinteiro e cunhado, Bartolomeu Bueno, de "umas cadeiras de presente de casamento". Na altura da morte da segunda esposa, Catarina de Unhate, em 1613, o gado se ampliou, os algodoais e teares surgem e também os escravos indígenas, inclusive alguns Pés-largos de uma entrada de Afonso Sardinha pelo sertão. Já nesse inventário, surge uma "alavanca", objeto fundamental na remoção de rochas e cascalho nos trabalhos de mineração e garimpagem no leito dos rios e córregos. Quando de seu próprio inventário, em 1624, surge a tal alavanca, mas surgem também três almocafres velhos, um "marco de quarta com sua balança" (para pesar ouro) e sete bateias de lavar ouro. Henrique da Cunha, entre os anos de 1613 e 1624, investiu na mineração ao longo de suas propriedades e ainda transmitiu a atividade aos filhos, deixando três bateias ao filho Henrique e três ao outro filho, Manoel, este morador vizinho de seu tio, Salvador Pires. De fato, seus netos participariam, inclusive, das descobertas de ouro nas minas geraes já no final do século XVII (I\&T, 1: 207 280). Afonso Taunay afirma ter sido Henrique da Cunha um dos descobridores de ouro em São Paulo, juntamente com os Sardinha (Taunay, 1975). Um seu irmão, João Gago da Cunha, possuía terras em Caucaia e era cunhado de Miguel de Almeida, um dos primeiros a ocupar o que viria a ser Guarulhos, com terras ao longo do rio Jaguari (I\&T, 10: 367).

O cunhado de Henrique, Matheus Leme, falecido em 1633, legou em seu inventário uma alavanca e dois almocafres. Além disso, tinha entre seus bens muito ferro bruto e instrumentos de ferro. Sua dívida com o provedor das minas e responsável pelos engenhos de ferro, Diogo de Quadros, mostram que Leme estava também envolvido nas atividades siderúrgicas, além da mineração de ouro. Matheus era, além disso, boticário e leitor de obras consideradas heréticas, como o Livro dos Segredos da Natureza, de Cesare Vanini, autor queimado vivo em 1619 e pensador da linhagem de Giordano Bruno. Suas terras, dedicadas à criação de gado e ao plantio de trigo, ficava na até agora insondável Toboapú. Pelo padrão de moradia de parentes próximos, bem como pelas atividades minerais, não seria excessivamente arriscado sugerir que tais terras estavam nas imediações do Baquirivu ou de Caucaia (I\&T, 9).

\section{Mineração e ocupação regional}

As atividades de mineração na região de Guarulhos foram um grande impulsionador de sua ocupação e da consequente expropriação das terras e do trabalho indígenas. Afonso Sardinha teria descoberto oficialmente algum ouro na serra do Itaberaba, na Cantareira, ainda em fins do século XVI. Essas descobertas, de Jaguamimbaba (Cantareira), Jaraguá, Voturuna (Santana de Parnaíba) e Caativa (até hoje sem localização definida) é que teriam atraído o governador geral do Brasil, Dom Francisco de Souza, a São Paulo (Franco, 1964). Até hoje não se sabe ao certo quanto de ouro se retirou dessas áreas minerais que, em trabalho recente de Nestor Goulart Reis (2013), fica-se sabendo que cobriram vastas extensões territoriais e um largo período de tempo. Configurou o que esse autor mesmo chamou de "Primeiro Ciclo do Ouro", e que teve em Guarulhos uma de suas áreas importantes de extração. Durante muito tempo, a historiografia minimizou essa atividade setecen- 
tista na Capitania de São Vicente, relegando-a a funções secundárias estritamente ligadas à garimpagem eventual e de pouca monta. Mais recentemente, a mineração em São Paulo do século XVII tem despertado uma maior atenção, sendo considerada uma atividade importante na lógica econômica da vila e imediações, o que permitiu algum nível de acumulação e troca, assim como servindo como baliza de expansão territorial (Vilardaga, 2013).

No caso da área coberta pelo atual município de Guarulhos, estudos geológicos vêm detalhando seu solo, sua composição mineral e mapeando suas áreas de extração, revelando a amplitude e importância da atividade mineradora na história da região (Juliani et al., 1995). Além disso, pode-se reconstituir as formas de garimpagem e de trabalho ao longo dos rios, córregos e ribeirões. As principais áreas de extração teriam sido próximas aos atuais "ribeirões das Lavras e Tomé Gonçalves e dos córregos Tanque Grande e Guaraçau” (Juliani et al., 1995: 6), além do rio Baquirivu-Guaçu, que compunham um amplo território permeado de lavras e envolvendo uma série de mineradores e trabalhadores. A presença abundante de água, e seu aproveitamento através de galerias, dutos, aquedutos e canais para lavagem, foi um fator preponderante para o sucesso de tais garimpos e lavras (Pérez-Aguilar et al., 2012). A presença da mineração na história regional ainda é perceptível nas marcas e vestígios materiais deixados na paisagem, compostos de galerias, escavações em encostas, desvios de rios e ribeirões, obras de drenagem, paredões, montes de rejeitos e entulhos. As lavras tiveram ainda um intenso desenvolvimento no século XVIII, e funcionaram seguramente até o início do século XIX (Pinheiro in Omar, 2008).

Dentre as fontes coevas que apontam para a exploração mineral em Guarulhos, estão: o livro de Anthony Knivet, que faz referências a depósitos de ouro em Mutinga, a uma aldeia indígena próxima ao rio Jaguari na qual existiam vasos de cerâmica com pepitas de ouro, e a uma serra próxima a São Paulo, "onde havia boa quantidade de ouro", e que bem poderia ser a serra do Itaberaba (Knivet, 2007); o relato de Guilherme Glimmer, inserido em Marcgrave, fala dos "montes guarimunis ou marumimins" onde tinha minas de ouro (RIHGSP, v. VI, 1900-1901); e o de João de Laet, que tenta precisar as minas de São Paulo e seus arredores (Reis, 2013).

A principal personagem relacionada à história da mineração em Guarulhos foi Geraldo Correa. Tanto seu inventário quanto o de sua esposa, Maria Soares, não sobreviveram ao tempo, restando apenas uma petição feita por dois de seus netos em 1672 (I\&T, 18: 261). Nessa, os dois reivindicam de seu tio, Estevão Sanches de Pontes, alguns índios, uma gargantilha de ouro de valor considerável $(11 \$ 000)$ e cortes de tafetá, legados pela avó.

Ao que parece, Geraldo Correa fora homem ligado ao governador geral Francisco de Souza, pois foi provisionado como avaliador e medidor de terras em São Paulo quando da chegada do mandatário à vila, em 1600 (RGCSP, 20/04/1600). De todo modo, sabemos que Geraldo Correa esteve na bandeira de Nicolau Barreto, que percorreu o sertão entre 1602 e 1604, e que teria avançado sobre terras paraguaias, chegando aos contrafortes do Alto Peru. Essa bandeira, ordenada pelo governador Francisco de Souza, tinha a tarefa de pesquisar minerais pelo sertão, mas trouxe uma outra riqueza: índios. Além disso, normatizou os trajetos interiores que interligavam o litoral vicentino ao Guairá, já no rio Paraná. Na expedição de Barreto, Geraldo aparece como fiador do inventário de Brás Gonçalves, morto no sertão, e no qual aparecem muitos índios Temiminós, um dos mais abundantes nas listas de "gente forra" dos inventários paulistas das quatro primeiras décadas do XVII (I\&T, 26: 5-39).

Para Francisco de Assis de Carvalho Franco, Geraldo teria descoberto ouro no rio Baquirivu em 1612 (Franco, 1954). A riqueza dessas minas é ainda um mistério. Um documento anônimo, e sem data, publicado no Livro Segundo do Governo do Brasil, intitulado "treslado da carta que veio de Sam Paulo sobre as minas de ouro que se am descuberto", relata a ida do responsável por uma das chaves da arca dos quintos conferir certo ouro trazido por Clemente Alvares - notório minerador de São Paulo colonial. Nesta averiguação, o ourives Claudio Furquim sentenciou que aquele ouro tinha 
"ventagem do de Seraldo", provavelmente a grande referência mineral no planalto (Livro $2^{\circ}$, 2001). Geraldo Correia, mais tarde chamado de o velho, ainda estava vivo em 1648, servindo de procurador de Catarina Cubas, filha do defunto Gaspar Cubas (I\&T, 37: 47-79).

Independente do ano preciso da descoberta, as minas do Geraldo ao longo do rio Baquirivu se tornaram referências e marcos definidores de limites de sesmarias na década de 1630, e nos ajudam a demarcar as novas levas de colonos que avançaram sobre as terras indigenas sob o pretexto da extração e beneficiamento mineral. João Nogueira de Pazes, Gonçalo Mendes Peres e Balthazar Correa, por exemplo, ganharam meia légua de terra cada um - em 1639 -, nas "cabeceiras" dos irmãos Costa - Simão, Álvaro e João - nas "minas de Geraldo Correa”. As minas referenciaram também a sesmaria de Álvaro Costa, concedida nesse mesmo ano de 1639 (Sesmarias, 1: 294-296). Um ano antes, Gregório Fagundes e Álvaro Rebello ganharam uma légua de terras nas "cabeceiras dos índios de Guarupiranga", correndo pelo sertão do rio Baquirivu, "ribeiro das minas que Geraldo Correa descobriu" (Sesmarias, 1: 248-250). Rebello era genro de Simão da Costa, proprietário local, e quando de sua morte, um ano depois de sua concessão, Geraldo Correa foi o curador de seus órfãos. Os Costa e os Correa, e seus cunhados e genros, passaram a monopolizar a posse de terras em torno das minas.

Os filhos de Geraldo, dentre eles Geraldo Correa, o moço, dariam continuidade às atividades do pai. No inventário de sua esposa, Estácia da Veiga, de 1674, aparece um sítio, com benfeitorias, "nas terras dos índios em São Miguel", chamado Maquerubu, o que denota - e reforça - alguma confusão em torno da jurisdição ao qual pertenciam aquelas terras, se aos índios de São Miguel ou de Nossa Senhora da Conceição. Além disso, há alguns poucos objetos de prata e instrumentos para garimpagem de ouro, como os velhos almocafres e alavancas, que ficariam para o neto do velho Geraldo, também homônimo. O casamento de Geraldo, o moço, com Estácia, selava a união entre os Correa e os Veiga, também antigos ocupantes de terras naquelas bandas (I\&T, 19: 95-97). A mãe de Estácia, Ma- ria da Cunha, fez seu testamento em 1670, no sítio que era da filha, em Caucaia, "no bairro de Nossa Senhora da Conceição”, onde um outro filho também tinha terras (I\&T, 17: 459-501). O termo bairro, de alguma forma, demonstra já um nível de ocupação sistemático, no qual as terras indígenas praticamente desapareciam no universo de referências espaciais.

Apesar da ocupação da região, das fazendas de trigo e gado que devem ter trazido alguma prosperidade ao território, e dos empreendimentos minerais, ainda na década de 1630 , a imagem daquelas bandas, para além da aldeia, parecia não ser das mais alvissareiras. No inventário de Francisco Rodrigues de Beja, falecido em 1634, e dono de um sítio em Caucaia, seu filho, Pedro Rodrigues, move ação contra a mãe de Estácia, Maria da Cunha, pois seu marido, Jerônimo, já falecido, teria levado um "negro da terra" que lhe pertencia ao sertão dos Guarulhos, onde o negro morreu "em sertão esteril que de contínuo morre gente de fome" (I\&T, 9: 227).

Assim, apesar de largamente ocupado, o território ainda guardava certa imagem de sertão longínquo e estéril. A aldeia, de fato, não havia sumido, pois Pedro Vaz Muniz, por exemplo, fez seu testamento, em 1670, na própria "aldeia de nossa senhora da conceição" (AESP, I\&T não publicados), mas já em 1685, o lugar era chamado de freguesia, como denota o registro de aforamento de terras passada a Pedro de la Guarda. Nesse registro, que pretende autorizar a criação de uma "casa de paragem", para a "conservação dos ditos Guarulhos", se faz referência a "um capão que está pegado à freguesia de Nossa Senhora da Conceição, indo para Hibitiratim", este um local pouco mais ao norte, já na direção do rio Juqueri, como demonstra a sesmaria dada a Antonio Madureira, em 1638. $\mathrm{O}$ registro de aforamento faz ainda referência a umas minas "de Camacho que por nome não perca”. Antonio Camacho tinha uma sesmaria no Cabuçu, concedida em 1610, e provavelmente seja uma referência às suas terras ou a de um seu descendente (Datas, doc. LXVIII).

Além do rio Baquirivu, um outro ribeirão, conhecido como Parati, atraiu a atenção dos moradores e mineradores. Geraldo Correa, o 
moço, e seu cunhado, Estevão Sanches de Pontes, ganharam sesmaria ali em 1638, cobrindo as duas margens do rio (Sesmarias, 1: 271-274). Faziam divisa com João Raposo Bocarro, que será, dentre outras coisas, provedor das minas de São Paulo; e também com os irmãos Gil, Antonio e Sebastião, toponímia, aliás, presente atualmente no Pico do Gil (Sesmarias, 1: 280-282).

Assim, configura-se uma ocupação sistemática que se espraiava ao longo dos rios Baquirivu e Jaguari; do ribeirão Parati, mais ao sul, e do rio Juqueri, desde suas cabeceiras, mais ao norte. Além disso, os assentamentos coloniais cobriam os sítios chamados de Caucaia, Cabuçu e Bananal, e as terras da própria aldeia. A exploração desse território, nítida região de fronteira em expansão, foi inicialmente centrada nas atividades agrícolas e pastoris, em especial o trigo, algodão e gado, e mais tarde na mineração, que se tornou destacada atividade.

É importante frisar, todavia, que a mineração em Guarulhos nunca se constituiu como uma atividade isolada, mas foi sempre acompanhada por culturas agrícolas e outras formas de exploração econômica. Nesse sentido, os Costa, os Correa, os Veiga, os Cunha, Leme, dentre outros, não tinham a mineração como atividade exclusiva, mas parte de um rol de beneficiamentos em suas propriedades essencialmente diversificadas. Desnecessário dizer que, para essas funções de exploração mineral - ademais para as outras -, a mão de obra foi principalmente a indígena, angariada dos sertões ou das aldeias. Pela proximidade, as minas do Geraldo, bem como outras adjacentes, serviram-se primordialmente dos índios Guarulhos de Nossa Senhora da Conceição.

De todo modo, não se pode descartar completamente a presença de escravos negros nos trabalhos nas minas no século XVII. A presença deles na documentação seiscentista, intitulados como "negros da Guiné" ou "tapanhumos", é mais rara e constitui importante fonte de riqueza nos inventários. Eram, muitas vezes, moedas de troca no comércio com o interior da América espanhola. Todavia, alguns poucos indícios sugerem uma presença diminuta no trabalho mineral. Se, por um lado, um dos importantes aliados do governador Francisco de Souza, Diogo de Quadros, provedor das minas, chegou a pedir ao Conselho da Índia em 1606 que pudesse repartir algo em torno de mil escravos negros entre os moradores de São Paulo para beneficiar as minas, mas teve seu pedido recusado pelo próprio governador, que deu um parecer ao Conselho, dizendo que o trabalho poderia ser feito por "índios naturais da terra que estão afastados de nós, se houver modo para os atraírem..." (Archivo General de Simancas; Secretarias Provinciales, Libro 1476, f. 164); por outro, ainda no começo do século XVII, mais precisamente em 1604, uma certidão feita pelo mineiro-mor do Brasil, Manoel Pinheiro Azurara relata que faltavam índios para o trabalho nas minas e que mesmo assim elas estavam sendo beneficiadas a partir do trabalho de alguns poucos índios, dos próprios moradores e de forasteiros com "escravos da guine" (Archivo Nacional de Assuncion, Civil y Criminal, 1549, 4, 1606). Duas décadas depois, em 1630, o sacerdote português Lourenço de Mendonça, que desejava explorar as minas de São Paulo, dizia que era possível beneficiar as minas com o trabalho dos muitos índios "de paz e conquistados" que existiam na vila, mas também dos "muchos negros de Angola" que lá chegavam todos os anos (Biblioteca Nacional do Rio de Janeiro, Castelo Melhor, 01, 02, 035, doc 16). De qualquer forma, os inventários disponíveis dos mineradores da região de Guarulhos apresentam muito poucos "negros da Guiné", como o de Henrique da Cunha.

Ainda em relação à presença de interesses minerais na região, cabe ressaltar que um dos mais famosos mineradores de São Paulo, Clemente Alvares, parceiro dos Sardinha e homem envolvido com ouro e ferro, não chegou, por exemplo, a ser personagem importante na região dos Guarulhos, mas assim mesmo possuía duas datas de terras ali, mais precisamente em Caucaia (I\&T, 14). Cláudio Furquim, ourives, aparece recorrentemente nos inventários da região como credor de dívidas. A presença de gargantilhas, anéis, brincos e outros objetos de ouro e prata, nos inventários, pode sugerir uma parte da origem das dívidas que cabiam a Furquim (I\&T, 5). Luiz Fernandes Folgado, no outro extremo dos termos da vila de São Paulo, 
em Santo Amaro, de onde tocava o Engenho de Ferro, chegou a pedir uma romaria a "Nossa Senhora da Conceição dos Maromemis", talvez indicando alguma devoção predileta dos mineradores e dos que trabalhavam os minérios (I\&T, 7: 449-493). A presença de Geraldo Correa, Henrique da Cunha e Matheus Leme naquelas paragens sugere que ali congregou-se uma comunidade de personagens envolvidos, familiarmente, nos negócios do ouro.

Jerônimo da Veiga, sertanista e um dos primeiros a se assentar em Guarulhos via casamento com Maria da Cunha, aparece em 1609 num processo movido em Assunção, no Paraguai, contra o mineiro-mor do Brasil, Manoel Pinheiro. Preso com cestas de erva mate contrabandeadas, Veiga acompanhou Pinheiro numa viagem considerada suspeita, pois se acreditava que com o mineiro vinham escravos negros e 12 quilos de ouro em contrabando (ANA, Civil y Judicial, 1549).

O ouro efetivamente retirado é somente especulado. Não há registro dele em inventários nem nas cobranças de quintos, afora alguns objetos de ouro esparsos e que poderiam servir para mascarar o mineral. Lourenço de Siqueira, também dono de terras em Guarulhos, e patriarca da linhagem que se tornaria proprietária da amplíssima Fazenda Bananal, na Guarulhos oitocentista, plantava trigo, criava gado, mas tinha também entre seus bens uma gargantilha, brincos e anéis de ouro, além de um "marco de pesar ouro", arrolado no inventário de sua mulher, Margarida Rodrigues (I\&T, 17: 25-29 e I\&T, 13: 45-93). A serra do Bananal foi também importante ponto de mineração, onde ficavam as lavras conhecidas como Tanque Grande.

Os registros minerais, de eventuais quintos, são quase inexistentes, o que dificulta uma aproximação dos níveis legais de extração. Os inventários só apresentam objetos em metal, nunca o mineral amoedado ou puro. Um levantamento feito pela pesquisadora Miriam Ellis (1950) identificou 200 quilos de prata e 19 de ouro. A ausência de prata nas minas regionais, bem como a enorme desproporção, indica uma sonegação sistemática do mineral aurífero mas sugere, por outro lado, uma provável intensa troca com a prata americana, passível de chegar ao planalto tanto pelos descaminhos atlânticos do Rio da Prata quanto pelos descaminhos interiores do Paraguai. A prisão de Jerônimo da Veiga é um indício destas conexões (Vilardaga, 2014).

De todo modo, algumas pistas podem reforçar a importância dessa extração mineral. Uma delas é a presença efetiva - que totalizou cerca de sete anos -, do governador geral Francisco de Souza em São Paulo. Em 1601, este mesmo mandatário proibiu a circulação de ouro em pó, o que em si denota uma prática que necessitou ser coibida (RGCSP, 11/02/1601). A instalação de uma Casa de Fundição, atuante desde a primeira década do século XVII, é outro dado importante. Por fim, em 1603, alguns mineiros trouxeram para São Paulo, diretamente de Espanha, um Regimento Mineral que duraria até 1618, quando um novo regimento, inteiramente voltado para as "minas de São Vicente”, foi registrado (Leme, 1980).

O Regimento de 1603 não especifica as formas de exploração do trabalho, resumindose à organização e ao regramento da ocupação das minas. Define tamanho das áreas, tempo para declarar e registrar as descobertas, liberdade de descobrimento, marcos de limites, instaura Casa de Fundição, reforça o papel da experiência das atividades mineradoras do Peru e Nova Espanha e define as funções do provedor das minas. Já o de 1618, direcionado para São Vicente, abre a exploração para índios e estrangeiros, desde que tivessem licença; limita as posses de minas para três por pessoa, vincula o provedor à Relação da Bahia; torna o provedor o repartidor dos índios nas minas e o responsável pelo regramento dessa exploração do trabalho, que implicava em: não permitir que se trabalhasse nas minas mais que o necessário, com limite de dias e pagamento acertado; seguir a lei de 1611, deixar gente nas aldeias para o plantio, enviar os índios para as minas próximas das aldeias, e visitar as minas a cada três meses para fiscalização. Ainda em 1644, um novo regimento demarcaria o poder sobre as minas em torno da pessoa de Salvador Correia de Sá e Benevides, pessoa não muito bem vista em São Paulo. Em relação à mão de obra, trazia a ressalva de não se utilizar "índios 
não domesticados nas minas" (Leme, 1980). Independentemente da quantidade de mineral extraído em São Paulo neste período - incluindo as minas de Guarulhos -, é fundamental levar em conta que grande parte da expertise que os paulistas aplicarão nas Minas Gerais e no Centro-Oeste ao longo do século XVIII foi adquirida exatamente nessas áreas minerais do planalto e também em Iguape e Paranaguá.

\section{Os índios e os capitães de aldeia}

Para além da mineração, uma outra fonte de riqueza altamente disputada na região, e em toda a Capitania, foi a população indígena. $\mathrm{O}$ próprio Lourenço da Siqueira é um caso exemplar. Siqueira foi sertanista, participando comprovadamente da bandeira de Lázaro da Costa, de 1615, que devassou o chamado "sertão dos carijós”, nas proximidades do rio Paraná. Nessa expedição, cumpria a função de alferes mor. Quando de seu testamento, em 1633, fez questão de pedir perdão por ter gentios da terra mantidos como escravos, mesmo sabendo-os livres. Pediu perdão ainda por ter praticado qualquer injustiça e não ter pago pelos serviços prestados pelos indígenas. Em seu inventário, aparecem nomeados 69 índios, entre homens, mulheres e crianças (I\&T, 13: 5-44).

Lourenço de Siqueira, de fato, não parece ter sido muito flexível com seu plantel de indígenas, como sugere o procurador do Conselho de São Paulo, em 1623, Luis Furtado, ele mesmo morador e proprietário nas proximidades de Nossa Senhora da Conceição. Furtado denunciou Garcia Rodrigues, o moço, que impedia o livre trânsito no antigo caminho real, que era utilizado pelos Guaramimis e pelos moradores da vila que negociavam com eles. Além disso, a via era usada para a romaria a Nossa Senhora da Conceição, o que denota já a força do culto religioso reservado àquela capela. Segundo a denúncia, o dito Rodrigues tratava mal os índios e confiscava os bens trazidos por eles. $\mathrm{O}$ pior é que parecia um negócio de família. O cunhado de Garcia era justamente Lourenço Siqueira, que praticava os mesmos atos em outro caminho que os índios tentaram abrir como alternativo. Lourenço era já foragido da justiça, e parecia participar da invasão das terras indigenas, denunciadas pelo mesmo procurador, na mesma sessão, que mandava os moradores tirarem as próprias criações de animais das terras dos índios Guaramimis (ACVSP, v. 3, 12/08/1623). Curioso ressaltar que Garcia Rodrigues era filho bastardo, mameluco, de Antonio Rodrigues Velho, comprado ainda garoto e alforriado somente quando da morte do pai, em 1616 (I\&T, 11: 47-53).

De todo modo, o abuso, a violência e a apropriação das terras indígenas era uma prática corrente entre os moradores de São Paulo e não seria diferente na aldeia de Nossa Senhora da Conceição. Algumas leis e provisões tentavam colocar algum freio na voracidade com a qual os moradores avançavam sobre as terras indigenas e sobre os próprios índios, um fenômeno conjunto. Vimos como a Câmara tentou fazer isso em 1625, mas desde o final do século XVI o capitão-mor da Capitania, Jerônimo Leitão, tentara proteger as terras indígenas, concedendo as sesmarias de São Miguel e Carapicuíba, e prevendo punições. Foi somente em 1622 que a Câmara registrou uma provisão de Felipe III, de 1604, para que "nenhuma pessoa roce terras dos indios" (RGCSP, I, 26/08/1622). De todo modo, aos poucos as regras foram simplesmente refletindo a prática de apropriação. Em 1682, os oficiais da Câmara solicitam que os "moradores que lavrassem nas terras dos índios fossem até a Câmara para fazerem aforamento" (RGCSP, II, 20/04/1682).

Ao longo do século XVII, uma certa decadência, como lembrou Pasquale Petrone, atingiu praticamente todos os aldeamentos do planalto. Segundo ele, havia uma concordância entre colonos, jesuítas e autoridades quanto à apropriação do trabalho indígena, mas a discordância vinha quanto aos meios e as formas. Em verdade, ocorreu uma verdadeira "sangria" das aldeias em função das demandas por mão de obra nas plantações de trigo, algodão e milho, pelas atividades mineradoras e pelas próprias expedições de apresamento de outros indígenas. A expulsão dos padres jesuítas em 1640 praticamente abriu as portas para a espoliação completa das aldeias (Petrone, 1995). 
A legislação indigenista também não ajudava muito. Para Petrone, elas nunca formaram um todo coerente. A lei de 1570, por exemplo, definia que só se cativassem indígenas em guerra justa, com licença do rei ou do governador. Essa, por sinal, foi a lei levada a cabo em São Paulo pelo governador Francisco de Souza, pois lhe dava nítidos poderes jurisdicionais sobre as expedições de apresamento e o destino dos cativos. Seja como for, em 1605 eliminou-se qualquer possibilidade de cativeiro e, em 1609, todos os índios foram considerados livres, mas com os jesuítas exercendo um protetorado exclusivo. Dois anos depois, contudo, em 1611, nova lei separou as funções clericais e seculares no trato sobre as aldeias. A liberdade foi reforçada, mas se estabeleceu a figura do capitão de aldeia, um senhor branco que deveria residir na aldeia, atuar como juiz e como organizador do trabalho dos índios, vivendo, em "troca" disso, à custa dos próprios indígenas. A aldeia deveria concentrar indígenas descidos do sertão, que ficariam a serviço de um "capitão" e sob os cuidados espirituais de um padre secular, que atuava junto à igreja, mais comumente uma capela, erguida no centro da comunidade aldeã. Claro que tal lei não agradou aos jesuítas que, em muitos casos, recusaram a lei de 1611 pela de 1609 (Petrone, 1995). É Azevedo Marques, por exemplo, que relata como o próprio Geraldo Correia assinou um documento com Henrique da Cunha Gago questionando os padres jesuítas que, muito provavelmente, teimavam em manter alguma jurisdição temporal sobre a aldeia de Nossa Senhora da Conceição (Marques, 1980). Os padres representavam um entrave aos potentados locais no usufruto da mão de obra indígena.

A figura do capitão dos índios dava, em realidade, grandes poderes aos senhores de terras das áreas adjacentes às aldeias. $\mathrm{O}$ mesmo Geraldo Correa, minerador e proprietário de grandes extensões - junto com seus parentes - das áreas do Baquirivu, foi capitão de aldeia, o que lhe deu livre trânsito sobre a população indígena. Antes dele, seu sogro também o fora e as suspeitas sobre ele não foram poucas. Ata da Câmara de 1607 fala de um requerimento feito por Gaspar Nunes, procurador dos índios forros, que foi ao Conselho com os principais das aldeias, para reclamar da nomeação de João Soares - sogro de Geraldo - como capitão dos indios. No requerimento, os indígenas diziam que não obedeceriam ao dito e prometiam desordens. A razão alegada era que João Soares fazia "muitos agravos" aos índios, mandando-os ao caminho do mar sem lhes pagar, recolhia órfãos em sua própria casa, os proibiam de terem plantação de mandioca e criação, e que os filhos de Soares pegavam as mulheres da aldeia e as levavam por onde queriam (ACVSP, II, 20/01/1607). Em verdade, João Soares - assim como Geraldo - faziam parte dos agraciados com mercês e ofícios do governador geral, pois fora ainda em 1600 nomeado capitão da aldeia de São Miguel (RGCSP, 25/05/1600) e, em 1607, como "capitão dos índios e da aldeia de Guarapiranga e da aldeia de Nova Eguanga e Jaguaporecuba”. Essa última fronteiriça com São Miguel, conforme se depreende dos limites da sesmaria de São Miguel concedida em 1580 (RGCSP, 16/11/1607).

Não sabemos os efeitos práticos do requerimento, mas as práticas de Soares não deveriam ser tão surpreendentes. No ano seguinte, em 1608 , o procurador ainda dava notícias de que os moradores iam às aldeias dos Maramomis "e lhes tomavam suas filhas e filhos contra suas vontades". Para o procurador, isso espantava os índios que vinham voluntariamente instalar-se ao redor da vila. O medo subjacente dos membros da Câmara era sempre o de um levante indígena, como aqueles que sacudiram a região nas décadas de 1560, 1590 e mais tarde, em 1650 (ACVSP, II, 05/10/1608).

Os casos parecem se repetir. Em outubro de 1617, Gonçalo Correia de Sá, capitão-mor da Capitania de São Vicente, nomeou Manuel Pinto como capitão das "aldeais dos Guaramimis” (RGCSP, 07/10/1617). No ano seguinte, o próprio Gonçalo avisava que "a mim vieram fazer queixa os índios gouamimis da aldeia de la vila de São Paulo que eles eram vexados e molestados por muitos homens brancos...". Para sanar as agressões, nomeou Gaspar Manoel Salvago, "procurador e advogado da Capitania", como capitão da aldeia, com poder de prisão (RGCSP, 08/1618). 
Outro proprietário local, que se tornou capitão de índios, foi João Raposo Bocarro, que em 1638 ganhou seis léguas de sesmarias nas duas margens do rio Paraty, que corria sertão adentro em direção ao rio Jaguari. $\mathrm{Na}$ concessão, as terras são localizadas na "banda dos Guarulhos", e são chamadas de "devolutas e desaproveitadas", um subterfúgio para a mera apropriação das terras (Sesmarias, I: 271-274). Bocarro, genro de Francisco de Siqueira, foi, além de capitão de aldeia e proprietário de terras, também provedor das minas que, pelos regimentos minerais de 1603 e 1618, tinha grandes poderes sobre toda a jurisdição mineral, o que incluía distribuir datas, concessões, fiscalizar mineradores e distribuir a mão de obra indígena, conforme algumas regras. Morador de Guarulhos, capitão de aldeia e oficial das minas, Bocarro deve ter exercido largos poderes sobre toda a região. Seu genro, falecido em 1698, ainda mantinha entre seus bens o "sítio em Guarapiranga em terras dos índios" (I\&T, 24: 175-192).

Foi possível localizar outros capitães da aldeia de Nossa Senhora da Conceição. João Martins Heredia, vereador em São Paulo em 1641, foi "capitão da aldeia dos Maramimis". Aleixo Leme registrou provisão para ser capitão dos índios da "aldeia de Nossa Senhora da Conceição”, em 1638 (RGCSP, II, 09/04/1638). Nos tumultuosos anos de 1652 e 1653 , nos quais os Guarulhos andavam alevantados, os capitães foram Martim da Costa, "dos índios guaromimis da aldeia de Nossa Senhora da Conceição", em 1652 (RGCSP, II, 09/11/1652), e Antonio Lopes de Medeiros, "capitão da aldeia dos Guarulhos”, em 1653. Lopes de Medeiros tinha a função de tirar os índios "das casas dos moradores donde estiverem", visto que a aldeia esvaziava a passos largos (ACVSP, VI, 25/08/1653).

As ações de Lopes de Medeiros devem ter sido inócuas, já que, em 1660, poucos anos depois, os oficiais da Câmara foram visitar a aldeia de Nossa Senhora da Conceição e "não encontraram nenhum gentio”. O capitão da aldeia na ocasião, Estevão Ribeiro, e o único índio ali presente, o "maioral da aldeia", o índio guarulho Diogo Martins, alegaram que todos se encontravam "nas casas dos moradores".
O resultado foi um novo clamor da Câmara para que os índios fossem devolvidos à aldeia (RGCSP, II, 27/07/1660). Como já dissemos, a prática era antiga. Pedro de Moraes Dantas, em seu testamento de 1648 , confessou ter em seu poder alguma "gente do gentio do Brasil", em especial Maria e Antonio guaninemis, da aldeia de Nossa Senhora da Conceição, onde tinham seus parentes. Dantas afirma, justificando-se, que eles eram livres para irem à aldeia quando quisessem, levando suas coisas e ferramentas (I\&T, 14: 287-297).

No documento de nomeação de Lopes de Medeiros se faz referência ao fato de que Francisco Rodrigues Velho já havia sido capitão de aldeia. Esse fato só corrobora a ideia de que efetivamente as aldeias indígenas eram entregues aos grandes proprietários das terras adjacentes que, invariavelmente, usavam de sua função para alocar os índios conforme suas conveniências. Francisco Rodrigues Velho, assim como seu irmão, Antonio Rodrigues Velho, foram potentados locais. Francisco era dono de uma sesmaria ganha em 1638 nas terras chamadas de Jaropebica, "taperas dos garomemis", seguindo até o rio Juqueri. Essas somavam-se às antigas terras de Francisco no Cabuçu, concedidas ainda em 1610 (Sesmarias, I: 255-257). Totalmente vinculado aos Siqueira e aos Cunha, Rodrigues Velho compunha o cenário de controle familiar do espaço guarulhense. Seu irmão, Antônio Rodrigues, era o pai do filho "bastardo" Garcia Rodrigues, que andava perturbando a vida dos índios pelos caminhos dos Guarulhos. O próprio Antônio foi capitão dos índios em 1609, conforme se conclui a partir de um requerimento feito pelo provedor das minas, Diogo de Quadros, em 1609. Esse, queixoso, protestava que há quatro anos estava na vila cuidando de desenvolver a mineração e o engenho de ferro, mas que no último ano "não tivera das aldeias mais que oito índios", esses dados por Antonio Rodrigues, "capitão dos marmemis dos índios" (ACVSP, II, 15/02/1609). Antonio, quando faleceu em 1616, deixou registrado em seu testamento que possuía uma "vaca preta de Nossa Senhora da Conceição dos Goaromimis”, e sua esposa, Joana de Castilhos, falecida em 1633, devia duas arrobas de cera a Nossa Senhora da 
Conceição (I\&T, 8, 335-357). De fato, além das terras e dos índios, todos os bens pertencentes à aldeia devem ter sido partilhados e usufruídos conforme os mais diversos interesses. Os tentáculos dessa família chegariam ainda mais longe. O genro de Antonio Rodrigues, Henrique da Cunha Lobo, venderia, em 1667, umas terras em "ururahy" ao padre Jacinto Nunes de Siqueira, que fundaria a igreja de Nossa Senhora da Penha nos anos posteriores.

O irmão do padre Jacinto, outro padre, Matheus Nunes Siqueira, esteve envolvido em outra fundação: a de Atibaia. Matheus desceu, "por seus meios", índios Guarulhos do sertão em 1665, com o intuito de promover a "salvação do dito gentio", sem nenhum interesse maior, dizia ele, que seu "fervor cristão". Os ditos índios foram alocados em Atibaia, onde o padre sugeria aos oficiais de São Paulo que se criasse uma aldeia, o que o Conselho pareceu acenar positivamente, apesar das graves notícias que davam conta de que alguns índios de um certo Manoel de Moraes tinham sido mortos pelos recém-chegados. Contudo, pouco mais de um ano depois, os oficiais ainda não haviam tomado posse da dita aldeia. (ACVSP, VI, 03/07/1665) O fato é que em 1669 , os oficiais da Câmara já reclamavam que os índios de Nossa Senhora da Conceição dos Guarulhos andavam abandonando a antiga aldeia e migrando para a de Atibaia. Mandaram notificar ao capitão de Guarulhos, o já reincidente Antonio Lopes Medeiros (que voltara à função desde 1661) $)^{3}$ que "pusesse cobro nos índios" (ACVSP, VI, 05/05/1669). Pelas discussões na Câmara, um certo frei "capuchinho barbado", de nome Gabriel, andava atraindo e acolhendo os "índios e índias goarulhos de sua majestade”, muitos provenientes de Nossa Senhora da Conceição. Conforme os oficiais, o tal frei amotinava os índios, estimulando a fuga de muitos deles de "seu senhor", causando

3 Conforme provisão e termos de juramento registrados na Câmara em 02/02/1661. A provisão foi dada por Salvador Correa de Sá e recomendava que Medeiros deveria "conservar os índios na aldeia não consentindo que se ausente nem que estejam espalhados em casas dos brancos para que assim possam servir a Republica pelas vias costumadas". "grande prejuízo deste povo e seus moradores" (ACVSP, VI, 13/05/1669). De fato, desde 1666, o capitão Lopes de Medeiros já pedia à Câmara, através de uma petição, que ajudasse a colocar freio nos moradores que "molestavam" os índios de Nossa Senhora da Conceição "em se pedindo suas terras". As petições, as fugas e a revolta violenta configuraram recursos claros de resistência e de imposição de limites aos colonos brancos por parte dos índios.

A reação dos moradores em relação à posse de "seus" índios sempre foi rápida. Em 1633, chegaram a invadir Barueri por causa de um conflito de jurisdição com os jesuítas e com a nova vila de Santana de Parnaíba, criada em 1625. Em 1624, todos regiram negativamente à ordem do governador geral do Brasil de que 1/5 de todos os índios descidos do sertão deveriam ser distribuídos entre as aldeias do Planalto e o envio à Bahia, para repovoar as zonas açucareiras. O oficial responsável por colocar em prática tal medida, Manoel João Branco, era provedor das minas e chegou a fazer uma cena patética na frente da igreja de São Bento, lendo sua provisão para algumas telhas, já que ninguém o ouvia. Em 1640, os jesuitas foram expulsos da vila de São Paulo depois de tentarem fazer valer uma bula papal de excomunhão aos que escravizassem indígenas. Em 1652, os oficiais da Câmara se negaram a cumprir uma provisão para que os índios de São Miguel fossem trasladados para Bertioga, pois consideravam uma desnaturalização dos índios (RGCVSP, II).

\section{Aldeia de Nossa Senhora da Conceição}

As aldeias indígenas, em forma de aldeamentos tocados por jesuítas ou colonos, tornaram-se base de administração do trabalho, e de defesa, da ocupação colonial em São Paulo. Implantadas em momentos, e circunstâncias distintas, desde a segunda metade do século XVI, os aldeamentos eram o manancial fundamental de onde os proprietários sacavam trabalhadores mais ou menos disponíveis. Era também o local onde se instalavam os indígenas que eram atraídos, ou apresados violentamente, nos sertões a partir das bandeiras. 
No conjunto, quer concentrado em aldeamentos ou fazendas dos jesuítas, quer trabalhando nas aldeias do padroado real, quer arregimentado na grande propriedade rural, em verdadeiras aldeias particulares, quer, ainda, distribuídos em pequenos contingentes pelas casas dos moradores como administrados, dispunham-se esses indigenas espacialmente dentro de um cinturão em torno do núcleo paulistano, verdadeira reserva de motores animados a serviço dos moradores europeus do núcleo ou dos arredores (Petrone, 1995: 202).

\section{Com a aldeia de Nossa Senhora da Con-} ceição não seria diferente. Ela foi organizada a princípio para abrigar os índios da categoria colonial guarulhos, identificados nas fontes comumente como maromomis, e outras tantas variáveis na estropiada grafia dos documentos quinhentistas e seiscentistas, como: marumumis, guarumemis, maramimis, marmemis, goaromimis, guanimemis, dentre outras formas. Vale ressaltar que o termo muitas vezes definia mais os indígenas que estavam num determinado lugar do que um grupo étnico bem definido. Na situação instável dos descimentos forçados de indígenas pelos sertanistas, as aldeias abrigavam quase sempre uma diversidade grande de grupos.

A própria aldeia dos Maromomis abrigava também os controvertidos Guaianases, considerados um dos primeiros grupos de habitantes do território que corresponde ao atual município de Guarulhos. Esses foram, desde o século XIX, alvo de intensa polêmica (Monteiro, 2001). No início, os historiadores e genealogistas paulistas consideraram que eles eram pertencentes ao grupo Tupi, o que os qualificava positivamente aos olhos dos linhagistas de muitas famílias paulistas, visto que muitas delas eram resultados de casamentos com índias Guaianases. Capistrano de Abreu, no começo do século XX, inspirado nos relatos de Gabriel Soares de Souza e Anthony Knivet, passou a defender que os Guaianases eram, como os Maromomis com quem compartilhavam territórios, grupos Jês, caçadores coletores. Eram, ambos, chamados de "gente andante" nos documentos de época (Abreu, 1988).
O pesquisador Benedito Prezia, que investigou mais a fundo os Maromomis, defende a tese de que eles viviam, ainda em 1630, na baía de Caraguatatuba, conforme indica um mapa de Albernaz desse ano que identifica essa baía como "Enseada dos Maromomis". Uma grande expansão Tupi do século XIV teria expulsado do litoral, e mesmo das zonas do planalto de São Paulo, grupos Puri, Guaianases e Maromomis, que teriam se refugiado na região da Mantiqueira, conhecida como "Monte dos Guarimunis ou Maruminis", conforme relato do perito mineral Glimmer, no começo do século XVII. Ainda para Prezia, os Maromomis passaram gradativamente a serem chamados de Guarulhos, nome que esses indígenas recebiam no Rio de Janeiro, onde também viviam perto de Cabo Frio (Prezia in Omar, 2008). O extermínio dos Tupinambás, quase completo no final do século XVI, teria permitido uma reocupação dos Maromomis que, antes refugiados na Mantiqueira, começaram a descer as encostas e ocupar o litoral paulista, chegando até o Espírito Santo. Isso talvez explique o nome da enseada de Caraguatatuba em 1630, e a suspeita de que os duzentos índios enviados por Francisco de Souza a São Paulo, do Espírito Santo, para acompanhar Diogo Arias de Aguirre em suas demandas minerais, eram Maromomis (Noronha, 1960). De todo modo, não deve passar despercebido o fato de que as primeiras investidas minerais do governador-geral em São Paulo tenham se dado com a previsão do uso da mão de obra dos Maromomis.

Conforme as descrições de Anchieta, Jacome Monteiro e Simão de Vasconcelos, todos eles jesuitas, os Maromomis eram considerados amigáveis aos portugueses, tinham apenas uma mulher, praticavam jogos, dormiam no chão, não eram antropófagos e possuíam uma língua fácil de aprender. Essas generalizações e classificações muito pouco dinâmicas, bastante comuns em documentos da época, mais nos atrapalham do que ajudam nas tentativas de compreensão da cultura dos grupos indígenas. De qualquer modo, a facilidade de apreensão linguística teria impulsionado o padre jesuíta Manoel Viegas, seguindo os passos de seu mestre José de Anchieta, que elaborara um catecismo tupi, a fazer uma 
versão Maromomi para lhe servir na tarefa de aldear esse grupo. Esse padre de origem portuguesa veio ao Brasil como órfão, e entrou para a companhia inaciana da Bahia em 1556, onde se ordenou em 1562. Em 1567 já estava em São Paulo, atuando ao lado de Anchieta, e foi um defensor da tese de que a catequese deveria ser feita a partir da língua do gentio. $O$ trabalho de Viegas foi bem-sucedido, visto que ficou conhecido como o "pai dos maromomis" ou, nos dizeres de seu mestre Anchieta, em 1596, o "apóstolo dos maromomis" (Viotti, 1984).

Entretanto, ainda existem muitas controvérsias sobre a data do início do aldeamento do Maromomis de Nossa Senhora da Conceição. A autorização formal da Companhia para que esses índios fossem aldeados no planalto é de 1604, o que contraria a tese sustentada por importantes historiadores regionais de que o aldeamento seria dos primeiros criados em São Paulo, ainda da década de 1560 (Prezia in Omar, 2008). De fato, tanto o relato de Fernão Cardim, de 1585, quanto uma carta do próprio Padre Viegas do mesmo ano, na qual relata que "se há de abrir agora aqui em São Vicente uma porta nova de um gentio que se chama maromemin e com eles se junta goiana, goianases e carijó, ibirabaquayra, e toda essa gente tem uma língua, de que eu já sei muito", indicam que o aldeamento é posterior a 1585 (Viotti, 1984: 388). Como Gabriel Soares de Souza, em 1587, já fala em quatro aldeias em torno de São Paulo, uma das possibilidades é a de que o aldeamento teria surgido por volta de 1586.

O Padre Simão Vasconcelos o cita como existente em 1609, ao lado de Pinheiros, São Miguel e Barueri, o que coincidiria em parte com as referências documentais presentes em testamentos, inventários e atas e registros da Câmara. Lembremos que desde 1607, quando se queria nomear João Soares como capitão dos índios, os Maromomis de Nossa Senhora da Conceição já aparecem reagindo. Por outro lado, ao longo das tensões em torno de Domingos Luiz, o Carvoeiro, em 1593, a respeito de uma índia Maromomi, fala-se somente em terras dos índios, não em aldeia.

Noronha (1960), estudioso da história de Guarulhos, defende que a aldeia foi criada ofi- cialmente para atender os maromomis em 1595, e que o Padre Viegas teria aldeado os maromomis não na aldeia dos guarús, onde haveria uma casa inaciana, mas no sertão, onde hoje é o bairro de Tapera Grande. Assim, defende a existência de dois lugares distintos. Um, onde se construiu a igreja de Nossa Senhora da Conceição, e no qual funcionava uma residência dos padres, e outro, onde os índios se instalaram e montaram sua aldeia, com uma capela.

Uma boa igreja teria sido construída pelo padre João Alvares, provavelmente na década de 1620. A identidade desse padre também é controvertida. Quer-se recusar que esse padre é o mesmo que construiu a capela de Nossa Senhora da Ajuda, de Itaquaquecetuba, e a de São Miguel, esta última com o carpinteiro espanhol Fernão Munhoz, em 1622. Isso pelo fato de que o padre foi também sertanista, dono de sesmaria em Mogi e acusado de ser "armador" de entradas, atividades pouco cristãs e virtuosas para um padre fundador. No nosso entender, a probabilidade desse padre, meio carpinteiro, ter participado da fundação das capelas desses três aldeamentos, contíguos, é efetivamente bastante alta.

A população indígena do aldeamento de Nossa Senhora da Conceição foi, ao largo de grande parte do século XVII, predominantemente de Guarulhos ou Maromomis. Alguns indícios sugerem a presença também de Guaianases, todos descidos violentamente ou atraídos ao aldeamento. Para John Monteiro (1988), os Guaianases e Maromomis foram alvos da sanha sistemática dos bandeirantes em pelo menos três momentos. Na primeira grande ofensiva da década de 1580 , levada a cabo pelo capitãomor Jerônimo Leitão. Uma segunda, na onda repressiva dos anos de 1592-1595, na esteira das revoltas indígenas de Pinheiros e dos ataques de Mogi. Essas expedições, muito mais voltadas aos Tupiniquins, teriam empurrado os Guaianá e os Guarulhos para o Vale do Paraíba e Serra da Cantareira. Por fim, depois da crise do abastecimento de índios guaranis na década de 1640, expedições de captura de Guaianases e Guarulhos foram organizadas em 1645, 1650 e 1661.

A presença de Guarulhos e Maromomis em inventários paulistas foi contabilizada por Ernani da Silva Bruno, se bem que ele separou 
os dois grupos. Na sua amostragem, pequena, visto que a maioria, cerca de 11.000 índios, não são identificados nos inventários, revela que: os Carijós vinham em primeiro lugar, com 371 índios em 53 documentos; os Temiminós em segundo, com 142 indígenas em 43 documentos; os Pés-largos em terceiro, com 38 índios em 18 documentos; os Guaianases com 30 índios, em 7 documentos; e os Guarulhos (27 em dois documentos) e os Maromomis (16 em 12). Se somarmos os dois como representantes de um único grupo, a soma de 43 índios os colocam na terceira posição nos inventários, o que reforça a importância desse grupo no plantel escravista dos moradores de São Paulo. (Bruno, 1976) A presença deles não se restringia, obviamente, aos inventários de moradores do entorno de Guarulhos, como bem mostra o rol de bens de Afonso Sardinha, de 1615, que legou alguns "guaramumins" aos padres da Companhia na aldeia de Carapicuíba (Marques, 1980).

Ao longo do século XVII, o território da aldeia de Nossa Senhora da Conceição de Guarulhos foi sendo gradativamente espoliado, tanto em seu manancial humano, quanto nas terras propriamente ditas. De sertão, passou a aldeia, a bairro, e, finalmente, à freguesia, num curto espaço de tempo no qual os indígenas foram os grandes perdedores. Não sem lutar! Não assistiram impassíveis à exploração e expropriação. Reclamaram pelos canais oficiais, fugiram continuamente, negociaram com proprietários em detrimento de outros, e passaram eventualmente para a luta aberta, gerando morte e destruição de várias famílias e propriedades escravistas.

A região, cobiçada e ocupada nas franjas das terras da aldeia no começo do século XVII, passou a ser sistematicamente distribuída entre os moradores, em núcleos familiares, a partir da segunda década daquele mesmo século. De fato, a ocupação iniciada nas cabeceiras vai gradativamente atingindo o cerne da aldeia a partir da década de 1660. As cartas de datas de terras revelam isso de forma direta. Um pedaço de terra "dos ditos índios", que corria até a aguada da aldeia, foi concedido aos irmãos Pedroso em 1660 (Datas, doc. XII). No mesmo ano, Mathias Lopes oficializou uma posse de "7 anos de uso" de um pedaço de "terras dos índios goaramimis”. Em 1679, Miguel Francisco Velho ganhou uma "terra de samambaias pertencentes aos índios da aldeia de Nossa Senhora da Conceição", consideradas eufemisticamente de devolutas e que corriam "além da igreja velha” (Datas, doc. XL). Os índios, cada vez mais raros, misturados e espalhados pelas propriedades, perdiam suas terras e sua base de reprodução cultural.

O plantio de trigo, algodão e milho, assim como a criação de gado, em Guarulhos, acompanharam a produção colonial do planalto de São Paulo, configurando os padrões de riqueza regional e representando apenas mais uma zona de expansão agrícola. A especificidade esteve presente na riqueza mineral. Nos veios de ouro e nos ribeirões auríferos que atraíram e formataram caminhos de ocupação e exploração. Apesar das riquezas minerais não terem gerado uma "febre de ouro" na região, ela mobilizou instituições, dinamizou leis e regramentos, justificou cargos e ofícios, e permitiu razoáveis níveis de riqueza. Como base de sustentação dessa economia regional: os Maromomis aldeados em Nossa Senhora da Conceição.

VILARDAGA, J. Land, gold and captivity: the indigenous village's of the Guarulhos occupation in the sixteenth and seventeenth centuries. R. Museu Arq. Etn., 26: 42-61, 2016

Abstract: This text - documental support and from the field of social history by archaeological research work of Guarulhos region (PIPAG) - analyzes the expansion and colonial occupation in the territory that would later constitute the municipality of Guarulhos. Focused on the sixteenth and seventeenth centuries, the research seeks to track the settlement of tenant farmers on dates and land grants and the modes of transmission of these properties among a few families. 
The text investigates ways of processing these lands, among them agricultural, pastoral setting and especially gold mining, the latter fundamental activity in the exploration of territory and little analyzed in the historiography. Finally, the paper discusses the interactions established between the colonists and the Indians, settled in the village of Nossa Senhora da Conceição of Guarulhos and vicinity, questioning the forms of indigenous agency.

Keywords: colonial expansion; indigenous agency; gold mining; Nossa Senhora da Conceição dos Guarulhos.

\section{Referências Bibliográficas}

Abreu, C. de. 1988. Caminhos Antigos e Povoamento do Brasil. São Paulo: Edusp/Itatiaia.

Actas da Câmara da Cidade de São Paulo. 1967. São Paulo: Publicação da Divisão do Arquivo Histórico; Divisão do Arquivo Histórico do Departamento de Cultura. 2. ed. v. 1 a 5.

Bontempi, S. 1970. O Bairro de São Miguel Paulista. São Paulo: Secretaria de Educação e Cultura; Prefeitura do Município de São Paulo.

Bruno, E. da S. 1976. "O que revelam os inventários sobre escravos e gente de serviço”. In: Revista do Arquivo Municipal, 188, janeiro a dezembro.

Cardim, F. 1980. Tratados da terra e gente do Brasil. Belo Horizonte: Itatiaia; São Paulo: Edusp.

Cartas, Informações, Fragmentos históricos e sermões do Padre Anchieta. 1933. Rio de Janeiro: Civilização Brasileira.

Ellis, M. 1950. Pesquisas sobre a existência do ouro e da prata no planalto paulista nos séculos XVI e XVII. In: Revista de História, USP, São Paulo: 1(1): 51-71.

Ferreira, B. 1971. Um homem exprime seu tempo. Revista do Arquivo Municipal. n. 182.

Franco, F. de A.C. 1932. Dom Francisco de Souza e o início do impulso bandeirante.
In: Revista do Instituto Histórico e Geográfico de São Paulo. v. XXIX.

Franco, F. de A.C. 1954. Dicionário de bandeirantes e sertanistas do Brasil - séculos XVI, XVII, XVIII. São Paulo: Comissão do IV Centenário da Cidade de São Paulo.

Franco, F. de A.C. 1964. História das minas de São Paulo. Administradores gerais e provedores (séculos XVI e XVII). Coleção História. São Paulo: Conselho Estadual de Cultura de São Paulo.

Inventários e testamentos. v. 1 a 47. São Paulo: Departamento do Arquivo do Estado de São Paulo (DAESP).

Juliani, C.; Beljavskis, P.; Juliani, L.J.C.O. 1995. As mineralizações de ouro de Guarulhos e os métodos de sua lavra no período colonial". Geologia Ciência - Técnica, 13: 8-25.

Knivet, A. 2007. As incriveis aventuras e estranhos infortúnios de Anthony Knivet. Rio de Janeiro: Jorge Zahar Editor.

Leme, P.T. de A.P. 1980. Nobiliarquia paulistana histórica e genealógica. Belo Horizonte: Editora Itatiaia; São Paulo: Ed. da Universidade de São Paulo.

Leme, P.T. de A.P. 1980. "Informações das minas de São Paulo e dos sertões de sua ca- 
pitania desde o ano de 1597, até o presente de 1772, com relação cronológica dos administradores delas". In: Notícias das Minas de São Paulo e dos sertões da mesma capitania. São Paulo: Edusp.

Livro 2 do Governo do Brasil. 2001. Lisboa: CNDP; São Paulo: Museu Paulista/USP.

Maffei, L.; Nogueira, A.R. 1966. O ouro na capitania de São Vicente nos séculos XVI e XVII. Anais do Museu Paulista, SP, v. 20: 7-135.

Marques, M.E. de A. 1980. Apontamentos históricos, geográficos, biográficos, estatísticos e noticiosos da província de São Paulo. Belo Horizonte - São Paulo: Itatiaia.

Monteiro, J.M. 1998. Negros da terra. Índios e bandeirantes nas origens de São Paulo. São Paulo: Companhia das Letras.

Monteiro, J.M. 2004. Dos Campos de Piratininga ao Morro da Saudade: a presença indígena na história de São Paulo. In: PORTA, Paula (Org.). História da Cidade de São Paulo. v. 1. A Cidade Colonial. Paula Porta. São Paulo: Paz e Terra.

Monteiro, J.M. 2001. Tupis, Tapuias e Historiadores: estudos de história indígena e do indigenismo. Tese de Livre-Docência, IFCH-Unicamp, 2001.

Noronha, A.V. 1960. Guarulhos cidade símbolo (história de Guarulhos) 1560-1960. São Paulo: Gráfica Schmidt.

Omar, E.O. (Org.). 2008. Guarulhos tem História: Questões sobre História Natural, Social e Cultural. São Paulo: Ananda Gráfica e Editora.

Pérez-Aguilar, A.; Juliani, C.; Barros, E. 2012. Reconstituição do sistema de transporte de água associado à lavra de ouro durante o período colonial nos arredores de Guaru- lhos, SP, Brasil. Revista do Instituto Geológico, São Paulo, 33 (1): 1-22.

Petrone, P. 1995. Aldeamentos paulistas. São Paulo: Edusp.

Pinto, L.C. 1980. Lutas de família no Brasil. Introdução ao seu estudo. Rio de Janeiro: Companhia Editora Nacional/INL/MEC.

Prezia, B.A. 2000. Os indígenas do Planalto Paulista nas crônicas quinhentistas e seiscentistas. São Paulo: Humanitas.

Prezia, B.A. 2004. Maromomi, os primeiros habitantes de Guarulhos. Prefeitura de Guarulhos e Espaço Cultural Florestan Fernandes.

Registro Geral da Câmara Municipal de São Paulo. 1917. v. I e II. Séculos XVI e XVII. São Paulo: Typographia Piratininga.

Reis, N.G. 2013. As minas de ouro e a formação das Capitanias do Sul. São Paulo: Via das Artes.

Sesmarias. 1921. Volume I. São Paulo: Typografia Paulista.

Souza, G.S. 1987. Tratado descritivo do Brasil. 1587. São Paulo, Brasília, DF: Ed. Nacional.

Taunay, A. 1975. História das Bandeiras Paulistas. São Paulo: Melhoramentos.

Vilardaga, J.C. 2013. As controvertidas minas de São Paulo (1550-1650). In: Varia Historia, Belo Horizonte, v. 29: 795-815.

Vilardaga, J.C. 2014. São Paulo no império dos Felipes: conexões na América Meridional (1580. 1640). São Paulo: Intermeios.

Viotti, H.A. 1984. Cartas: correspondência ativa e passiva José de Anchieta. São Paulo: Edições Loyol 